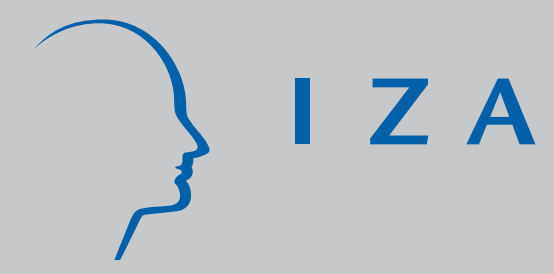

IZA DP No. 3162

Principal Accountability at Private Secondary Schools

Sherrilyn M. Billger

November 2007 


\title{
Principal Accountability at Private Secondary Schools
}

\author{
Sherrilyn M. Billger \\ Illinois State University \\ and IZA
}

Discussion Paper No. 3162

November 2007

\author{
IZA \\ P.O. Box 7240 \\ 53072 Bonn \\ Germany \\ Phone: +49-228-3894-0 \\ Fax: +49-228-3894-180 \\ E-mail: iza@iza.org
}

\begin{abstract}
Any opinions expressed here are those of the author(s) and not those of the institute. Research disseminated by IZA may include views on policy, but the institute itself takes no institutional policy positions.

The Institute for the Study of Labor (IZA) in Bonn is a local and virtual international research center and a place of communication between science, politics and business. IZA is an independent nonprofit company supported by Deutsche Post World Net. The center is associated with the University of Bonn and offers a stimulating research environment through its research networks, research support, and visitors and doctoral programs. IZA engages in (i) original and internationally competitive research in all fields of labor economics, (ii) development of policy concepts, and (iii) dissemination of research results and concepts to the interested public.
\end{abstract}

IZA Discussion Papers often represent preliminary work and are circulated to encourage discussion. Citation of such a paper should account for its provisional character. A revised version may be available directly from the author. 
IZA Discussion Paper No. 3162

November 2007

\section{ABSTRACT}

\section{Principal Accountability at Private Secondary Schools ${ }^{*}$}

Increasing interest in voucher programs and privatizing public schools reveals a commonlyheld belief that private schools are better able to produce a quality education. While state and national standards do not directly affect these schools, their private control yields strong student performance. To contribute to the general discovery about private schools, I use SASS and Census data to investigate accountability and outcomes at private secondary schools, focusing on principals, student outcomes, and administrator effectiveness. I find that principals are not rewarded for facing accountability or for exercising autonomy. OLS and quantile regression results also suggest no direct benefit for strong students at high quality schools. However, accountability does improve student outcomes at the (conditionally) weakest schools.

JEL Classification: J3, 12

Keywords: principal pay, accountability, private schools

Corresponding author:

Sherrilyn M. Billger

Department of Economics

Illinois State University

Campus Box 4200

Normal, IL 61790-4200

USA

E-mail: smbillg@ilstu.edu

*I would like to thank Rajeev Goel, Dan Rich, James Payne, and CeMENT workshop participants for helpful comments and discussion. 
1 Accountability and Performance at Private Schools

In an open letter on educational standards, the presidents of the two national school principal organizations stated,

Any model of accountability, including testing, must consider a principal's needs for the resources and authority to make critical decisions that affect student achievement, such as choosing curricula; controlling budgets; hiring, firing, and rewarding staff members; and providing appropriate professional development for teachers. (Ferrandino and Tirozzi, 2001)

Formal regulation that holds public schools accountable for student performance is relatively new, but private schools likely have a longer history of accountability, given their governance structures. Therefore, an investigation of accountability at private schools can inform current debates about public schools. ${ }^{1}$ In addition, private schools are often heralded as high-quality alternatives to public schools, but limited data are available to test such claims. Much remains to be learned about private schools, particularly concerning whether principals are able to impact student outcomes.

Addressing these concerns, I investigate the determinants of principal pay and student outcomes in the private sector, a market not subject to recent standards, but with greater freedom in setting both goals and educator compensation. Indeed, private schools may perform better than public schools, because their students seem quite different from those at public schools. Unsurprisingly, Lankford and Wyckoff (1992) find that families decide whether to send their children to private schools based upon school quality, tuition, and socioeconomic characteristics. However, according to Sander (1999), private schools do not directly affect public school test scores or graduation rates.

It nonetheless seems that students gain from switching to private schools. For instance, Ferris and West (2002) state that students in danger of dropping out of school may benefit from voucher programs that effectively reduce their costs. Barnard et al. (2003) further find that

\footnotetext{
${ }^{1}$ Some recent studies of public school accountability include Hastings and Weinstein (2007), Billger (2007), and Hanushek and Raymond (2005).
} 
students participating in a voucher program in New York attained higher math scores. Hoxby (2004) also reveals that public school productivity has declined substantially in recent decades. Addressing quality more generally, Bishop and Woessmann (2002) note that centralized standards, matched with school autonomy in process and personnel would improve public school performance. Also valuable are parental involvement and competition from private schools. Privately-controlled schools are also more likely to use merit pay, as stated in Ballou (2001), so accountability for these educators may be well-established. It is likely that private school principals are similarly rewarded for their performance and expertise. Thus, using OLS and quantile regressions, I explore pay and expertise, focusing on the presence of accountability, parental involvement, principal autonomy, and student outcomes that relate to school quality.

\section{Describing Private School Principals}

Data on secondary schools are compiled from the 1999-2000 U.S. Schools and Staffing Survey (SASS) and combined with community data from the 2000 U.S. Census, which are merged to the school-level data by zip code. SASS is a detailed nationally-representative survey with data on private schools and principals, including resources, demographic characteristics, specific tasks, and assessments of school problems and strengths. For instance, a principal's self-reported influence over curriculum and hiring is available, as well as indicators of parental involvement. Unfortunately, high-quality test score data are unavailable for private schools. Therefore, I focus on other indicators of student performance: attendance rates and the percentage of previous year's seniors who pursue a 4-year college education. ${ }^{2}$

Summary statistics for the secondary schools in this analysis appear in Table 1. Principal salaries average $\$ 47410$, and are lower than those at public schools. In the absence of expenditure data, which is unavailable for private schools, tuition provides a measure of relative

\footnotetext{
${ }^{2}$ Kane and Staiger (2002) argue that using test scores to investigate accountability can lead to misinterpretations of the true effectiveness.
} 
expenses across schools, and averages $\$ 4807$ in these data. While accountability measures such as statewide goals are not directly applicable to private schools, there are other indicators of accountability. For instance, $82 \%$ of private schools have governing councils that determine curricula and performance standards. In addition, approximately 14\% of private secondary school principals claim that their school "has a long way to go" before achieving their educational goals, suggesting that these schools are subject to pre-determined standards (and are not doing well). It also appears that these principals are well-set to respond to goals, as they have extensive influence over performance standards and hiring.

\section{The Effect of Accountability on Principal Salary}

According to Ballou (1995), teachers rate principal performance higher for those with more teaching experience, while graduate training yields lower ratings. Assuming that performance and pay are highly correlated, I specify principal salary at private secondary schools as follows:

$$
\text { lsalary }=f(X, S, C, A, I)
$$

The matrix $X$ contains principal data for education and experience and school characteristics included in $S$ are: $\ln ($ enrollment), percent minority enrollment, pupil-teacher ratio, $\ln$ (maximum tuition), school location, and school affiliation (Parochial/Diocese, private order Catholic, conservative Christian, other religious, and nonsectarian). ${ }^{3} C$ represents the percent of the adult population in the community who have earned a BA/BS degree. Added later are accountability measures $A$ for governing council and "long way to go" on educational goals, as well as influence factors $I$ for principal's influence and parental involvement. $f(\cdot)$ denotes, in turn, linear and quantile regression functions.

Baseline OLS estimates reveal mean effects. Presumably, a principal's salary reflects their performance on many tasks that are not included in a survey such as the SASS, and the mean of

\footnotetext{
${ }^{3}$ Studies of private schools generally include only three categories: Catholic, other religious, and nonsectarian. However, extensive variation within these categories necessitates finer distinctions. In addition, as school finance data are not available for private schools, tuition necessarily serves as a proxy for expenditures.
} 
the conditional salary distribution is thus assumed to represent the mean unobserved performance. It may certainly be true that residual variation results from factors other than performance, but it nevertheless seems reasonable to assume that higher conditional salaries are substantially determined by the strong performance of the principal, particularly at private schools. This notion of unobserved performance is much like the convention in the labor economics literature in which the error term reflects innate ability (see, e.g., Arias et al. (2001) and Hallock et al.(2004)).

As the error term in salary regressions reflects a measure of performance, the distribution provides a useful measure of variation. Thus, positive correlations between unobserved performance and expertise reveal that the best principals see higher returns to their education and experience. Positive relationships between a governing council and unobserved performance suggest that better principals receive greater rewards when held accountable. In order to investigate these sorts of correlations, I also estimate quantile regressions. ${ }^{4}$ The $\theta^{\text {th }}$ regression quantile is the solution to

$$
\min _{\beta \in R^{K}}\left[\sum_{i \in\left\{i: y_{i} \geq x_{i}^{\prime} \beta\right\}} \theta\left|y_{i}-x_{i}^{\prime} \beta\right|+\sum_{i \in\left\{i: y_{i}<x_{i}^{\prime} \beta\right\}}(1-\theta)\left|y_{i}-x_{i}^{\prime} \beta\right|\right]
$$

where $\theta \in(0,1)$. This yields the minimum of the weighted sum of absolute deviations, with unique parameter estimates at different quantiles of the conditional distribution of the dependent variable. To obtain heteroskedasticity-robust estimates, results were generated from 500 bootstrapping repetitions.

Coefficient estimates are presented in Figure 1, displaying OLS estimates and quantile coefficients at each decile with a $90 \%$ confidence band. Experience appears to have relatively uniform effects throughout the conditional salary distribution. Enrollment has a decreasing monotonic effect; the return to size is largest for the lowest-paid principals. Highly-paid

\footnotetext{
${ }^{4}$ Koenker and Hallock (2001) introduce quantile regressions as originally developed in Koenker and Bassett (1978).
} 
principals receive a pay premium for leading a school with more minority students, suggesting that the best administrators deal well with diversity. Confidence intervals for experience and the pupil-teacher ratio include the OLS estimate, suggesting no significant difference across quantiles.

A selection of accountability measures are added to above salary specification. In the absence of controls such as state-wide performance goals, included indicators reveal: the presence of a school council that determines performance standards and curricula and whether the principal indicates that the school "has a long way to go" on educational goals. Additional possibilities include an indicator for professional development programs for teachers and the presence of state government accreditation. However, these measures have consistently insignificant effects on salaries and other regressors, and are thus omitted from this discussion.

Results for the impact of accountability on private secondary school principal salaries appear in Table 2. While the mean effect of a governing council is insignificant, such a council is positively associated with salaries for the lowest paid principals, suggesting a factor which compresses the salary distribution. On the other hand, if the school has a "long way to go," salaries are substantially lower. It could be that weak schools simply pay less, or that weak principals who do not improve their school receive lower pay. Indicators for the principal's relative influence and parental involvement are also included as they may explain some of the relationship between accountability and pay. The positive impact of a governing council on the lowest-paid (lowest-performing) principals disappears, suggesting that the effect is highly correlated with principal influence and/or parental involvement at private schools.

4 Accountability, College Matriculation, and Student Attendance Rates

Some previous literature reveals ways principals may enhance school quality. For instance, Brewer (1993) finds that student outcomes improve if principals make good hiring decisions and 
set appropriate goals. According to Eberts and Stone (1988), curriculum choices and teacher evaluations are also particularly important. To supplement the general discovery in this area, I begin by regressing college attendance on school and community characteristics.

$$
\text { college attendance rate }=f(S, C, A, I)
$$

Private secondary school characteristics $(S)$ are as defined in equation (1). $C$ includes a relative teacher salary measure (salary for a teacher with a BA and 10 years of experience divided by local per-capita income) and the percent of the adult population who hold a Bachelor's degree. Accountability measures $A$ and influence factors $I$ appear in additional specifications, and as above, both OLS and quantile regression estimates are obtained.

Parameter estimates are displayed in Figure 2. School size has a more positive impact at the schools with the lowest college matriculation rates, suggesting no economies of scale benefits for schools above median quality. However, ceteris paribus, higher pupil teacher ratios are less damaging at high quality schools. Perhaps unsurprisingly, high tuition yields better outcomes, but the largest effect is at the conditionally worst schools (those with the lowest matriculation controlling for observed characteristics).

Results from the inclusion of accountability and influence are presented in Table 3. These accountability measures appear to be uncorrelated with college attendance rates at private schools, contrary to the effect found for principal salary. Unsurprisingly, parental involvement is significantly positively associated with school performance. The mean impact appears upward biased though, and the correlation declines monotonically through higher quantiles. This suggests that parental involvement is less important at stronger private schools.

As an additional measure of principal performance on student outcomes, I estimate the determinants of daily student attendance rates in the school:

$$
\text { student attendance rate }=f(S, C, A, I)
$$


where the functions and arguments are as defined for specification (3). Predicted OLS and quantile regression coefficients appear in Figure 3. Higher pupil-teacher ratios are correlated with lower attendance rates, with the strongest relationship at the conditionally lowest quality schools; larger classes seem particularly detrimental to this day-to-day performance measure. Also interesting is the highly positive effect of community education level; in struggling schools, a community value for education is correlated with students going to school more regularly. Teacher salaries are also significant. Well-paid teachers and engaged students appear to arise in tandem, particularly at the weakest schools.

According to OLS results, the presence of a governing council is negatively correlated with student attendance, perhaps reflecting that a struggling school is more likely to face accountability from a council. On the other hand, being a "long way" from meeting educational goals is correlated with better outcomes, at least in quantiles near the median. The positive effect of teacher salaries remains, yielding much higher attendance rates at the (conditionally) worst schools.

It is further possible that principal salaries and student outcomes are directly related. Regressions run with principal salary as an additional regressor do not reveal such a relationship, except at the conditional mean of college matriculation. Salary regressions further revealed that only student attendance has a significant effect, and that is also at the mean. In fact, this relationship appears negative, suggesting that, ceteris paribus, principals receive lower pay for higher attendance rates. Taking together, these results do not suggest a strong correlation, let alone an endogenous relationship. Oddly enough, principal salary and student outcomes appear to be quite separately determined in private secondary schools.

\section{Conclusion}


In this study I investigate the relationships between accountability and principal compensation and performance at private secondary schools. Because private schools are not subject to stateor district-wide accountability measures, I investigate the role of governing councils and the principal's assessment of progress toward educational goals. I find that the presence of a governing council improves salaries for the lowest-performing principals and, in certain cases, is correlated with lower student attendance rates, but such a council does not effect college matriculation. Poor progress toward educational goals is correlated with lower salaries and lower college matriculation. However, student attendance is improved, suggesting that increasing attendance may be an important factor for schools struggling to meet educational goals.

Somewhat surprisingly, these principals are not substantially rewarded for exercising autonomy, mirroring the effect on student outcomes. On the other hand, parental involvement is clearly important for improving college attendance, and monotonically decreasing coefficients reveal that parents can alleviate problems at lower quality schools. Another interesting finding is the positive relationship between relative teacher salary and student attendance at the (conditionally) weakest schools. This result is consistent with a hypothesis that well-paid teachers can benefit lower quality schools, where student attendance is more likely to be a concern.

Though government agencies do not hold private schools to the same standards as public schools, these institutions nonetheless have mechanisms for monitoring quality. Accountability, as measured here, is rarely positively related to principal compensation or student outcomes, and the main exception is for student attendance. It seems that goals and standards are most effective for struggling students at struggling schools. 
References

Arias, Omar, Kevin F. Hallock, and Walter Sosa-Escudero, (2001) "Individual Heterogeneity in the Returns to Schooling: Instrumental Variables Quantile Regression Using Twins Data," Empirical Economics, 26(1), pp. 7-40.

Ballou, Dale, (2001) "Pay for Performance in Public and Private Schools," Economics of Education Review, 20, pp. 51-61.

Ballou, Dale, and Michael Podgursky, (1995) "What Makes a Good Principal? How Teachers Assess the Performance of Principals," Economics of Education Review, 14(3), pp. 243-52.

Barnard, John, Constantine E. Frangakis, Jennifer L. Hill, and Donald B. Rubin, (2003) "Principal Stratification Approach to Broken Randomized Experiments: A Case Study of School Choice Vouchers in New York City," Journal of the American Statistical Assocation, 98(462), pp. 299-311.

Billger, Sherrilyn M., (2007) "Principals as Agents? Investigating Accountability in the Compensation and Performance of School Principals," Industrial and Labor Relations Review, October 2007, 61(1), pp. 90-107.

Bishop, John. H., and Ludger Woessmann, (2002) "Institutional Effects in a Simple Model of Education Production," Education Economics, 12(1), pp. 17-38.

Brewer, Dominic J., (1993) "Principals and Student Outcomes: Evidence from U.S. High Schools," Economics of Education Review, 12(4), pp. 281-92.

Eberts, Randall W., and Joe A. Stone, (1988) "Student Achievement in Public Schools: Do Principals Make a Difference?” Economics of Education Review, 7(3), pp. 291-9.

Ferrandino, Vincent L., and Gerald N. Tirozzi, (2001) “Dear Mr. President,” Education Week, 21 February.

Ferris, J. Stephen, and Edwin G. West, (2002) "Education Vouchers, the Peer Group Problem, and the Question of Dropouts," Southern Economic Journal, 68(4), pp.774-93.

Hallock, Kevin F., Regina Madalozzo, and Clayton G. Reck, (2004) "Uncovering Heterogeneity in Managerial Pay - Firm Performance Relationships Using Quantile Regression," Unpublished Paper, University of Illinois.

Hallock, Kevin F., (2002) "Managerial Pay and Governance in American Nonprofits," Industrial Relations, 41(3), July, pp. 377-406.

Hanushek, Eric A., and Margaret E. Raymond, (2005) "Does School Accountability Lead to Improved Student Performance?” Journal of Policy Analysis and Management, 24(2), pp. 297327.

Hastings, Justine S., and Jeffrey W. Weinstein, (2007) "No Child Left Behind: Estimating the Impact on Choices and Student Outcomes," NBER Working Paper No. 13009. 
Hoxby, Caroline M., (2004) "Productivity in Education: The Quintessential Upstream Industry," Southern Economic Journal, 71(2), pp.209-31.

Kane, Thomas J., and Douglas O. Staiger, (2002) "The Promise and Pitfalls of Using Imprecise School Accountability Measures," Journal of Economic Perspectives, 16(4), pp. 91-114.

Koenker, Roger, and Kevin F. Hallock, (2001) “Quantile Regression,” Journal of Economic Perspectives, 15(4), pp. 143-56.

Koenker, Roger, and Gilbert Bassett, Jr., (1978) "Regression Quantiles," Econometrica, 46(1), pp. 33-50.

Lankford, Hamilton, and James Wyckoff, (1992) "Primary and Secondary School Choice among Public and Religious Alternatives," Economics of Education Review, 11(4), pp. 317-37.

Sander, William, (1999) "Private Schools and Public School Achievement," The Journal of Human Resources, 34(4), pp. 697-709. 
Figure 1. OLS and Quantile Regression Estimates
Dependent Variable is $\ln ($ Private Principal's Salary)
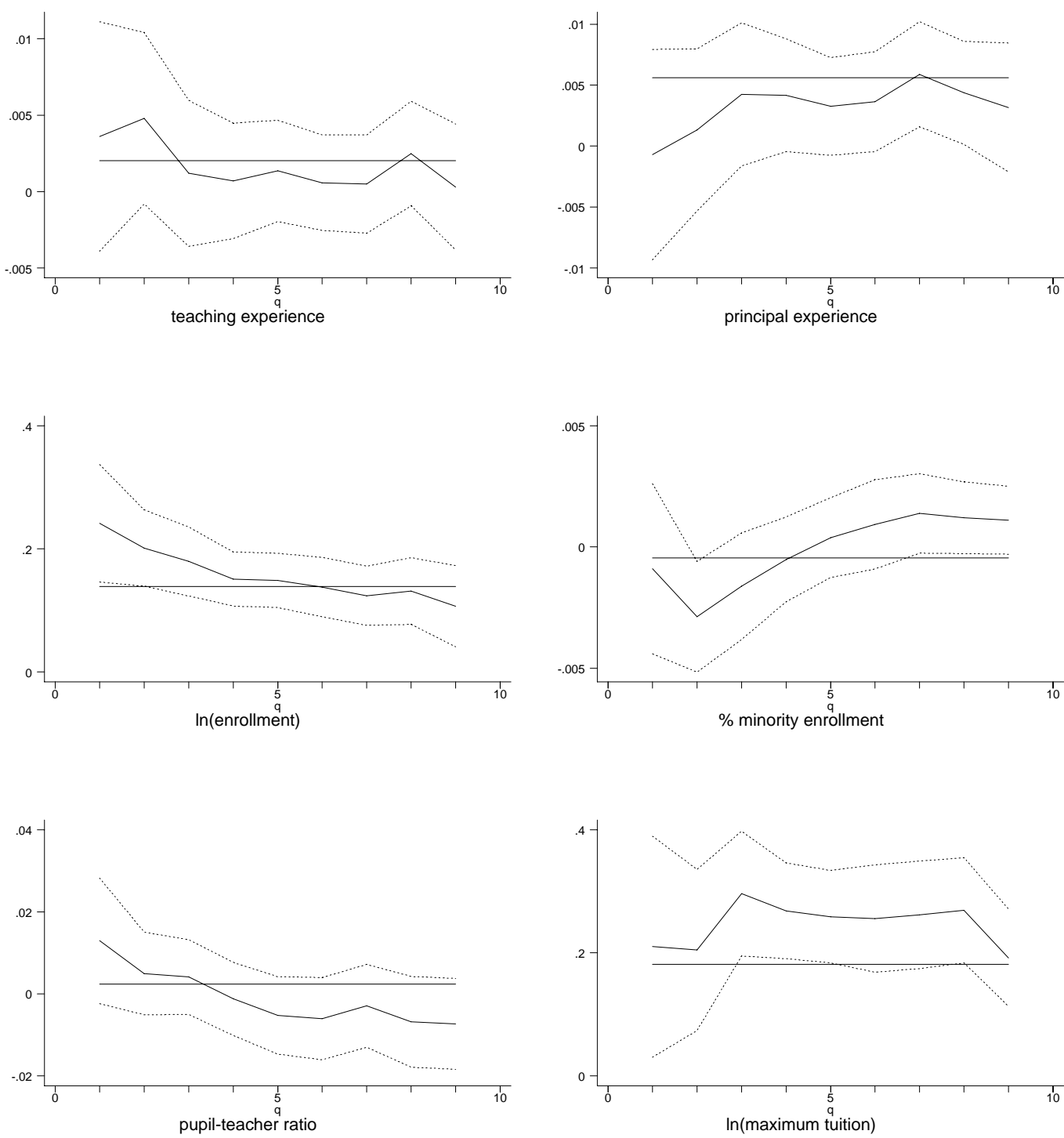

Data: Private Secondary Schools from 1999-2000 SASS, 2000 U.S. Census.

Quantiles along $\mathrm{x}$-axis represent quantiles in the conditional distribution of $\ln$ (principal salary). Quantile regression estimates presented with $90 \%$ confidence intervals.

Additional regressors include: degree attainment, age, school location, gender, race/ethnicity, school affiliation (Parochial/Diocese, private Catholic, conservative Christian, other religious, nonsectarian), and percentage of adult population with $\mathrm{BA} / \mathrm{BS}$. 
Figure 2. OLS and Quantile Regression Estimates

Dependent Variable is Percentage Private Graduates Attending 4-year College
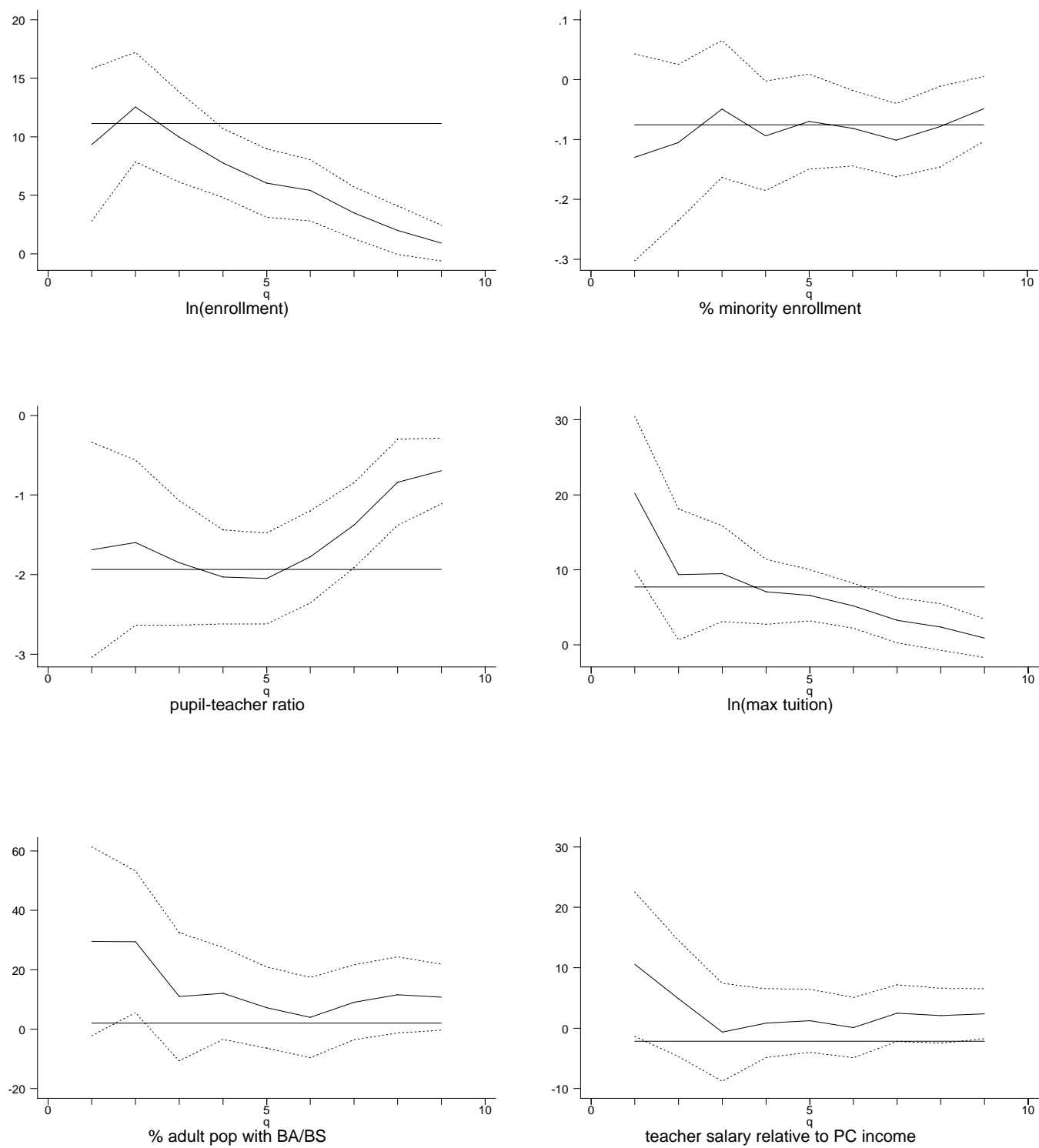

Data: Private Secondary Schools from 1999-2000 SASS, 2000 U.S. Census.

Quantiles along x-axis represent quantiles in the conditional distribution of college attendance. Quantile regression estimates presented with $90 \%$ confidence intervals.

Additional regressors include: school location and affiliation (Parochial/Diocese, private Catholic, conservative Christian, other religious, nonsectarian). 
Figure 3. OLS and Quantile Regression Estimates

Dependent Variable is Student Attendance Rate
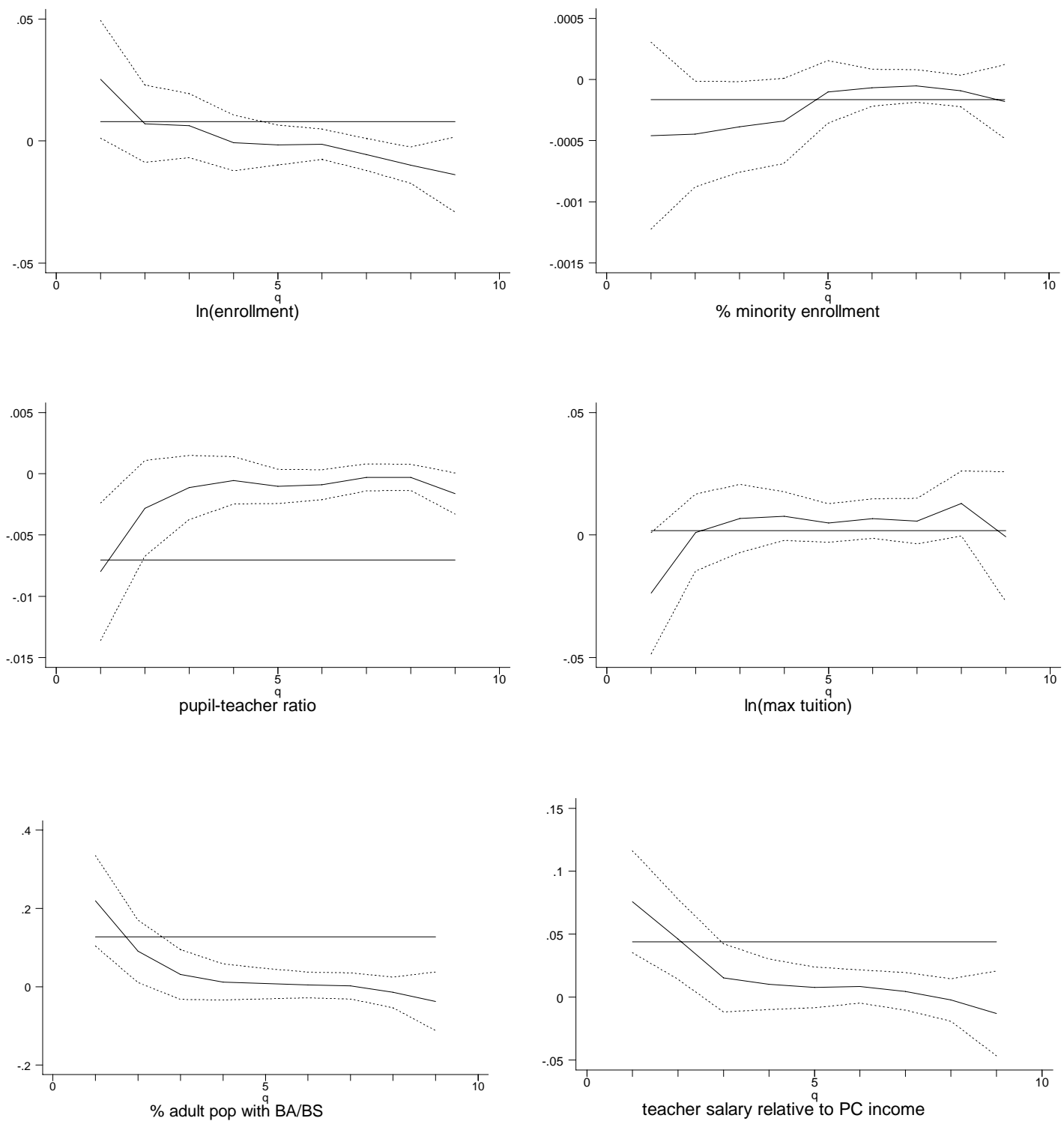

Data: Private Secondary Schools from 1999-2000 SASS, 2000 U.S. Census.

Quantiles along $\mathrm{x}$-axis represent quantiles in the conditional distribution of student attendance rate. Quantile regression estimates presented with $90 \%$ confidence intervals.

Additional regressors include: school location and affiliation (Parochial/Diocese, private Catholic, conservative Christian, other religious, nonsectarian). 
Table 1. Summary Statistics for Principals and Their Schools

Private School Variables

\begin{tabular}{rr} 
Mean & St. Error \\
\hline 47410.41 & 1611.822 \\
15.064 & 0.563 \\
10.244 & 0.440 \\
323.387 & 15.066 \\
11.513 & 0.247 \\
18.434 & 1.268 \\
4806.52 & 246.70 \\
0.817 & 0.023 \\
0.137 & 0.019 \\
0.423 & 0.025 \\
& \\
0.738 & 0.024 \\
0.905 & 0.016 \\
0.748 & 0.025 \\
61.967 & 2.186 \\
726 &
\end{tabular}

Data: National Center for Education Statistics: Schools and Staffing Survey 1999-2000, 2000 National Assessment of Educational Progress, 2000 Common Core of Data; 2000 U.S. Census. 
Table 2. School Accountability and Private School Principal Salaries

\begin{tabular}{|c|c|c|c|c|c|c|}
\hline Panel A. DepVar $=\ln ($ principal salary $)$ & OLS & Q 0.1 & Q 0.25 & Q 0.5 & Q 0.75 & Q 0.9 \\
\hline \multirow[t]{2}{*}{ School Has Governing Council } & -0.025 & $0.307 * *$ & $0.188^{*}$ & 0.072 & 0.043 & 0.033 \\
\hline & $(0.069)$ & $(0.147)$ & $(0.098)$ & $(0.063)$ & $(0.047)$ & $(0.063)$ \\
\hline \multirow[t]{2}{*}{ School Has "Long Way to Go" on Educ. Goals } & $-0.190 * *$ & -0.146 & $-0.191 *$ & -0.077 & -0.080 & -0.072 \\
\hline & $(0.078)$ & $(0.158)$ & $(0.103)$ & $(0.050)$ & $(0.050)$ & $(0.061)$ \\
\hline R-squared & 0.476 & & & & & \\
\hline Panel B. DepVar = $\ln$ (principal salary) & OLS & Q 0.1 & Q 0.25 & Q 0.5 & Q 0.75 & Q 0.9 \\
\hline \multirow[t]{2}{*}{ School Has Governing Council } & 0.004 & 0.216 & 0.156 & 0.102 & 0.065 & 0.073 \\
\hline & $(0.066)$ & $(0.155)$ & $(0.098)$ & $(0.063)$ & $(0.052)$ & $(0.068)$ \\
\hline \multirow[t]{2}{*}{ School Has "Long Way to Go" on Educ. Goals } & $-0.170^{* *}$ & -0.159 & -0.166 & -0.070 & -0.062 & -0.102 \\
\hline & $(0.081)$ & $(0.161)$ & $(0.106)$ & $(0.053)$ & $(0.051)$ & $(0.066)$ \\
\hline \multicolumn{7}{|l|}{ Principal's Influence: } \\
\hline \multirow[t]{2}{*}{ exceeds district's on performance standards } & 0.015 & 0.070 & 0.023 & 0.026 & 0.017 & 0.027 \\
\hline & $(0.056)$ & $(0.106)$ & $(0.055)$ & $(0.034)$ & $(0.044)$ & $(0.055)$ \\
\hline \multirow[t]{2}{*}{ exceeds district's on hiring teachers } & -0.014 & 0.055 & -0.056 & -0.048 & -0.004 & 0.071 \\
\hline & $(0.088)$ & $(0.178)$ & $(0.086)$ & $(0.053)$ & $(0.060)$ & $(0.084)$ \\
\hline \multirow[t]{2}{*}{ exceeds teachers' on hiring teachers } & $0.165^{* *}$ & 0.012 & 0.043 & 0.035 & 0.038 & -0.086 \\
\hline & $(0.075)$ & $(0.117)$ & $(0.058)$ & $(0.045)$ & $(0.058)$ & $(0.076)$ \\
\hline \multirow[t]{2}{*}{ No problem with parental involvement } & 0.042 & -0.008 & 0.009 & 0.027 & 0.039 & $0.083^{*}$ \\
\hline & $(0.056)$ & $(0.099)$ & $(0.051)$ & $(0.031)$ & $(0.035)$ & $(0.046)$ \\
\hline R-squared & 0.490 & & & & & \\
\hline Number of Observations & 726 & & & & & \\
\hline
\end{tabular}

$* * *, * *$, and $*$ denote significance at the $0.01,0.05$, and 0.10 level, respectively.

OLS results incorporate robust standard errors and NCES sampling weights, and quantile regression estimates result from 500 bootstrap repetitions.

Additional regressors include: degree attainment, age, school location, gender, race/ethnicity, teaching and principal experience, ln(enrollment), \% minorities, pupil-teacher ratio, $\ln (\max$ tuition), school affiliation (Parochial/Diocese, private Catholic, conservative Christian, other religious, nonsectarian),

percentage of adult population with BA/BS, and a constant term. Panel B specifications also include an indicator for academic excellence as principal's main goal. 
Table 3. School Accountability and College Attendance Rate

\begin{tabular}{|c|c|c|c|c|c|c|}
\hline Panel A. DepVar = college attend rate & OLS & Q 0.1 & Q 0.25 & Q 0.5 & Q 0.75 & Q 0.9 \\
\hline \multirow[t]{2}{*}{ School Has Governing Council } & -3.929 & -1.795 & 1.727 & 1.437 & 0.520 & 0.903 \\
\hline & $(4.652)$ & $(5.319)$ & $(4.529)$ & $(2.962)$ & $(1.606)$ & $(1.328)$ \\
\hline \multirow[t]{2}{*}{ School Has "Long Way to Go" on Educ. Goals } & 0.622 & 5.291 & 3.329 & -2.208 & $-3.473 * *$ & -2.851 \\
\hline & $(4.916)$ & $(7.300)$ & $(4.665)$ & $(2.761)$ & $(1.720)$ & $(1.741)$ \\
\hline R-squared & 0.435 & & & & & \\
\hline Panel B. DepVar = college attend rate & OLS & Q 0.1 & Q 0.25 & Q 0.5 & Q 0.75 & Q 0.9 \\
\hline \multirow[t]{2}{*}{ School Has Governing Council } & -2.979 & -5.381 & 4.379 & 2.307 & 0.656 & 0.747 \\
\hline & $(4.613)$ & $(6.070)$ & $(4.804)$ & $(2.840)$ & $(1.910)$ & $(1.651)$ \\
\hline \multirow[t]{2}{*}{ School Has "Long Way to Go" on Educ. Goals } & 2.941 & 0.035 & 4.227 & -2.220 & $-3.622 * *$ & -2.949 \\
\hline & $(4.782)$ & $(7.207)$ & $(4.320)$ & $(2.536)$ & $(1.706)$ & $(1.962)$ \\
\hline \multicolumn{7}{|l|}{ Principal's Influence: } \\
\hline \multirow[t]{2}{*}{ exceeds council's on performance standards } & -1.533 & -2.070 & 1.418 & 1.929 & 0.797 & -1.188 \\
\hline & $(3.291)$ & $(5.431)$ & $(3.407)$ & $(2.106)$ & $(1.641)$ & $(1.652)$ \\
\hline \multirow[t]{2}{*}{ exceeds council's on hiring teachers } & -2.169 & 2.864 & 0.744 & 3.004 & 2.799 & 2.438 \\
\hline & $(6.476)$ & $(7.921)$ & $(4.550)$ & $(2.413)$ & $(1.806)$ & $(1.816)$ \\
\hline \multirow[t]{2}{*}{ exceeds teachers' on hiring teachers } & 3.146 & -5.258 & 6.653 & 6.288 & $5.465^{*}$ & 1.154 \\
\hline & $(4.247)$ & $(6.363)$ & $(5.255)$ & $(4.111)$ & $(3.310)$ & (3.411) \\
\hline \multirow[t]{2}{*}{ No problem with parental involvement } & $8.454 * * *$ & 7.467 & $7.768^{* * *}$ & $4.328^{* *}$ & $2.494 * *$ & 1.636 \\
\hline & $(3.197)$ & $(5.426)$ & $(2.886)$ & $(1.771)$ & $(1.254)$ & $(1.218)$ \\
\hline R-squared & 0.459 & & & & & \\
\hline Number of Observations & 536 & & & & & \\
\hline
\end{tabular}

$* * *, * *$, and $*$ denote significance at the $0.01,0.05$, and 0.10 level, respectively.

OLS results incorporate robust standard errors and NCES sampling weights, and quantile regression estimates result from 500 bootstrap repetitions.

Additional regressors include: school location, $\ln$ (enrollment), \% minorities, pupil-teacher ratio, $\ln (\max$ tuition), school affiliation

(Parochial/Diocese, private Catholic, conservative Christian, other religious, nonsectarian), percentage of adult population with BA/BS,

teacher salary relative to per-capita income, and a constant term. Panel B specifications also include an indicator for barriers to dismissing teachers

(from policies, tenure, assoc.) and an indicator for academic excellence as principal's main goal. 
Table 4. School Accountability and Student Attendance Rate

\begin{tabular}{|c|c|c|c|c|c|c|}
\hline Panel A. DepVar = student attendance rate & OLS & Q 0.1 & Q 0.25 & Q 0.5 & Q 0.75 & Q 0.9 \\
\hline \multirow[t]{2}{*}{ School Has Governing Council } & $-0.086^{*}$ & -0.012 & -0.010 & -0.002 & -0.013 & -0.038 \\
\hline & $(0.052)$ & $(0.017)$ & $(0.010)$ & $(0.007)$ & $(0.010)$ & $(0.024)$ \\
\hline \multirow[t]{2}{*}{ School Has "Long Way to Go" on Educ. Goals } & 0.018 & 0.021 & $0.027 * *$ & 0.010 & $0.006^{* *}$ & 0.012 \\
\hline & $(0.018)$ & $(0.020)$ & $(0.011)$ & $(0.008)$ & $(0.011)$ & $(0.017)$ \\
\hline R-squared & 0.126 & & & & & \\
\hline Panel B. DepVar = student attendance rate & OLS & Q 0.1 & Q 0.25 & Q 0.5 & Q 0.75 & Q 0.9 \\
\hline \multirow[t]{2}{*}{ School Has Governing Council } & $-0.089 *$ & -0.014 & -0.015 & -0.004 & -0.012 & -0.040 \\
\hline & $(0.050)$ & $(0.018)$ & $(0.010)$ & $(0.008)$ & $(0.010)$ & $(0.027)$ \\
\hline \multirow[t]{2}{*}{ School Has "Long Way to Go" on Educ. Goals } & 0.020 & 0.026 & $0.027 * *$ & $0.014^{*}$ & 0.008 & 0.011 \\
\hline & $(0.019)$ & $(0.021)$ & $(0.011)$ & $(0.008)$ & $(0.010)$ & $(0.017)$ \\
\hline \multirow[t]{2}{*}{ Ln(Teacher Salary/Per-Capita Income) } & $0.043 *$ & $0.073 * * *$ & $0.033^{*}$ & 0.007 & -0.004 & -0.002 \\
\hline & $(0.025)$ & $(0.027)$ & $(0.018)$ & $(0.010)$ & $(0.009)$ & $(0.021)$ \\
\hline \multicolumn{7}{|l|}{ Principal's Influence: } \\
\hline \multirow[t]{2}{*}{ exceeds council's on performance standards } & -0.007 & -0.007 & -0.008 & -0.003 & -0.005 & -0.008 \\
\hline & $(0.015)$ & $(0.018)$ & $(0.010)$ & $(0.007)$ & $(0.005)$ & $(0.008)$ \\
\hline \multirow[t]{2}{*}{ exceeds teachers' on hiring teachers } & 0.017 & 0.010 & -0.003 & 0.001 & 0.010 & $0.017 *$ \\
\hline & $(0.015)$ & $(0.031)$ & $(0.013)$ & $(0.007)$ & $(0.007)$ & $(0.010)$ \\
\hline \multirow[t]{2}{*}{ No problem with parental involvement } & 0.019 & -0.010 & -0.010 & 0.001 & 0.005 & 0.009 \\
\hline & $(0.023)$ & $(0.017)$ & $(0.009)$ & $(0.005)$ & $(0.004)$ & $(0.007)$ \\
\hline R-squared & 0.136 & & & & & \\
\hline Number of Observations & 537 & & & & & \\
\hline
\end{tabular}

$* * *, * *$, and $*$ denote significance at the $0.01,0.05$, and 0.10 level, respectively.

OLS results incorporate robust standard errors and NCES sampling weights, and quantile regression estimates result from 500 bootstrap repetitions.

Additional regressors include: school location, $\ln$ (enrollment), \% minorities, pupil-teacher ratio, $\ln (\max$ tuition), school affiliation

(Parochial/Diocese, private Catholic, conservative Christian, other religious, nonsectarian), percentage of adult population with BA/BS,

teacher salary relative to per-capita income, and a constant term. Panel B specifications also include an indicator for barriers to dismissing teachers

(from policies, tenure, assoc.) and an indicator for academic excellence as principal's main goal. 